\title{
Financial Innovation and Demand for Money in Nigeria
}

\section{Joshua Nsikak Jonah}

Statistics Department, Central Bank of Nigeria (CBN), Abuja, Nigeria

\section{Idaka Sunday Egbe}

Department of Accounting, Faculty of Management Sciences, University of Calabar, Calabar, Nigeria

Eja Basil Richard (Corresponding Author)

Department of Banking and Finance, Faculty of Management Sciences, University of Calabar, Calabar, Nigeria Email: ejabasil@yahoo.com

\author{
Article History \\ Received: 2 April, 2020 \\ Revised: 10 October, 2020 \\ Accepted: 22 December, 2020 \\ Published: 27 December, 2020 \\ Copyright (C) 2020 ARPG \& \\ Author \\ This work is licensed under the \\ Creative Commons Attribution \\ International \\ (ᄄ) $(6)$ \\ c) CC BY: Creative \\ Commons Attribution License \\ 4.0
}

\begin{abstract}
This study examined the impact of financial innovation on money demand in Nigeria, using quarterly time series for the period 2009-2019. The dependent variable was money demand, represented by broad money, while the independent variable was financial innovation represented by modern payment channels such as volume of Automated Teller Machines (ATMs) transactions, volume of Point of Sales (POS) transactions, volume of Internet banking transactions, and volume of Mobile banking transactions. The study employed the ordinary least squares (OLS) regression technique as the estimation method within the cointegration, granger causality, and error correction modelling. The result obtained showed that financial innovation has mixed impact on money demand in Nigeria during the period of analysis. For instance, financial innovation has positive impact on money demand through volume of ATM transactions in the current period, two periods lagged of volume of mobile banking transactions, current period and one period lagged of volume of internet banking transactions, and current period's volume of Point of Sales (POS) transactions in Nigeria. On the other hand, financial innovation has negative impact on money demand through one period lagged of volume of point of sales in Nigeria. On the stability of the demand for money function, the result of the stability tests based on the CUSUM test and CUSUM of squares test showed that the demand for money function was stable during the evaluation period. The study recommended that monetary policy strategy of the central bank of Nigeria (CBN) should be fine-tuned to ensure it is well suited to deal with the challenges posed by financial innovation by way of proliferation of sophisticated payment channels.
\end{abstract}

Keywords: Financial innovation; Demand for money; Financial products; Nigeria.

\section{Introduction}

In Nigeria, the financial system has gone through series of reforms over the course of time, with the aim of positioning it to perform optimally and efficiently and therefore contributes positively to economic growth and development. These reforms have culminated in the emergence of new financial products and services into the Nigerian financial system. The successful introduction and operation of these services have been boosted by the evolution in information and communication technology (ICT) currently taking place in the country. With the coming on board of mobile telecommunication and internet services in the country, the financial system is now bubbled with flurry of financial products, financial instruments and financial services including the utilization of prepaid/credit/debit cards for electronic payments through the Automated Teller Machines (ATMs), Point of Sale (POS) terminals, mobile banking, internet banking, personal computer banking, and Real-Time Gross Settlement System (RTGS), amongst others.

Conceptually, financial innovation means the emergence of new financial products, instruments, financial services, and new forms of organizational structure in the financial system (Solans, 2003). Financial innovation performs vital roles, including helping the financial system to work efficiently, which ultimately facilitates the operation of monetary policy, reducing transaction costs via higher productivity of capital, which results in rapid economic growth and development, and promoting financial intermediation in the financial system (Nkoro and Uko, 2013; Noyer, 2008). On the other hand, financial innovation can affect adversely the performance of the monetary policy and could complicate the environment in which monetary policy operates (Noyer, 2008). For instance, with the existence of modern financial products, contractionary monetary policy targeted at reducing excess liquidity can be undermined as economic agents can easily move money from less liquid holdings to more liquid packages being offered by financial intermediaries and in the process undermine monetary policy performance (Gbadebo, 2010) .

In particular, the financial innovation by way of evolution in financial technology, products and services could affect the effective functioning of the demand for money function. With financial innovation, the demand for money function could become unstable and makes the velocity of money demand function unpredictable. The instability of the demand for money function brought about by financial innovation could have far-reaching consequence on 
monetary policy decision. For instance, the greater use of this alternative form of money is capable of substituting for the traditional form of money, which diminishes the demand for money to the extent that it can replace the use of other liquid financial instruments, thereby undermining the effectiveness of monetary policy formulation.

The relationship between the demand for money and factors determining its behaviour provides the bedrock in macroeconomic theories and is an important component in the formulation and implementation of monetary policy in any economy (Goldfeld, 1994). Thus, investigating the impact of financial innovation on money demand is very expedient because studying how financial innovation affects money demand function will help in the formulation of effective monetary policy in Nigeria. The objective of this study is to examine the impact of financial innovation on money demand in Nigeria. The specific objectives are (1) to examine the impact of financial innovation by way of evolution of modern and sophisticated payment channels on demand for money in Nigeria (2) to test for the stability of demand for money function in Nigeria. This study is significant in that its findings will provide information on the performance of the financial system in Nigeria and how the emergence of financial innovation by way of introduction of modern payment channels has fared in Nigeria. Such assessment will be beneficial to the government, the monetary authorities, and monetary economists when formulating policies to enhance the development of the financial sector in Nigeria. The study is segmented into 5 sections. Section 1 is the introduction. Section 2 reviews empirical studies and theories relating to the study. Section 3 presents the methodology of the study. Section 4 analyses the results and section 5 concludes the study and offers policy recommendations.

\section{Literature Review}

\subsection{Empirical Studies}

Gbadebo and Okunrinboye (2009) carried out investigation on the impact of financial innovation on the demand for money in Nigeria, utilizing time series data from 1970 to 2004. The study applied the Engle and Granger TwoStep Co integration technique and found that financial innovation has negative and significant effect on the demand for money in Nigeria. Other results of this paper showed that interest rate on deposit and treasury bills have negative impact on the demand for money in Nigeria, while real income and price level are positively related to money demand in Nigeria.

Hye (2009) undertook investigation on the link between financial innovation and money demand in Pakistan during the period of 1995-1 to 2007-12 using the robust techniques of co-integration and error correction mechanism (ECM). The result of the co-integration test showed that that there exists a long run relationship among the variables. The result of the short run dynamics revealed that financial innovation has statistically significant effect on money demand in Pakistan both in the long and in the short run. The study revealed that the short run elasticity was larger than the long run elasticity during the period.

Misati et al. (2010) examined the impact of financial innovation on monetary policy transfer mechanism, focusing particularly on the impact of financial innovation on the interest rate channel of the monetary transmission mechanism in Kenya using monthly data covering from 1996 to 2006. Employing the Two Stage Least Squares (2TLS) technique, the study found that financial innovation has a weakening effect on the interest rate channel of money transmission mechanism. This result implies that financial innovation has posed a serious challenge to the conduct of monetary policy in Kenya.

Matthew et al. (2010) examined the effect of financial innovations on demand for money in Nigeria for the period spanning from 1970 to 2008, using the Engle and Granger Two-Step Cointegration technique. The cointegration result showed that there was a long run association among the variables. Result of the error correction model showed that financial innovation has negative and significant influence on money demand in Nigeria.

Sichei1 and Kamau (2012) carried out study on the effect of financial innovation on demand for money in Kenya, using quarterly data for the period spanning from 1997:4 to 2011:2. The authors used the number of ATMs as a proxy for financial innovation. The cointegration analysis was performed for the study. The result showed that there was no significant effect of financial innovations on the demand for money.

Safdar and Khan (2014) carried out a study on the effect of financial innovation on money demand and the effect of money market disequilibrium on output gap in Pakistan, utilizing the ordinary Least Squares (OLS) estimation technique. The study used number of Automated Teller Machines (ATMs) as a measure of financial innovation. The result of the estimation revealed that financial innovation by way of number of ATMs has negative impact on money demand in Pakistan.

Aliha et al. (2017) empirically examined the impact of financial innovation on money demand for a panel of 215 countries for the period, spanning from 2004 to 2013. The General Method of Moment (GMM) was used in the estimation of the relationship. The result of this study showed that financial innovation, represented by number of ATMs has negative effect on money demand. This means that an increase in the number of ATMs by $1 \%$ brought about a decrease in money demand by about $0.01 \%$.

Apere (2017) carried out a study on the impact of financial innovation on demand for money in Nigeria, utilizing data for the period covering from 1981 to 2016, employing the Vector Autoregression (VAR) methodology as estimation method. Outcome of the estimation showed that financial innovation has a negative influence on the demand for money in Nigeria. This according to the author is that as financial innovation increases, people tend to move away from a more liquid asset to not too liquid assets

Mujuri et al. (2018) investigated the impact of financial innovation on demand for money function in Kenya, utilizing data from 2008 to 2016. The study employed the Autoregressive Distributed Lag (ARDL) technique, based on the Bounds testing approach. The result of the study showed that financial innovation impacted positively on 
demand for money function in Kenya. Specifically, volume of ATM exerted positive and significant effect on demand for money in Kenya

From the review, it is noticed that few studies exist in Nigeria examining the impact of financial innovation on demand for money. These studies do not seem to use modern payment channels such as the Automated Teller Machines (ATMs) transactions, Mobile banking transactions, Point of Sale (POS) transactions, and Internet banking transactions in their analysis. This is the main focus of this study and departure from the previous studies in Nigeria and the gap the study filled.

\subsection{Theoretical Framework}

This section reviews theories relating to the subject matter of investigation in this study. The relevant theories reviewed included the financial innovation hypothesis, diffusion of innovation theory, the classical theory of money demand, the Keynesian theory of money demand and the monetarist theory of money demand.

\subsection{Financial Innovation Hypotheses}

Financial innovation hypothesis was developed following empirical studies carried out by various authors like Merton (1992), Allen and Gale (1994), and Grinblatt and Longstaff (2000). The financial innovation hypothesis exists in two versions: financial innovation - growth hypothesis and financial innovation-fragility version. The main proposition of the financial innovation hypotheses is derived from various theoretical literature and empirical investigations carried out by authors to investigate the impact of financial innovation on economic growth. According to the financial innovation - growth hypothesis, financial innovations plays a very important function in the financial system by helping in the reduction of agency costs, facilitating sharing of risks in the financial system, helping in improving the quality and variety of banking services, and ultimately enhances allocative efficiency in the financial system (Allen and Gale, 1994; Berger, 2003; Grinblatt and Longstaff, 2000; Houston et al., 2010; Merton, 1992).

Deducing from this proposition, it means that financial innovation has ability of raising the efficiency of the financial system by increasing the variety of financial products and services, which leads to improvement in matching individual savers requirements with firms searching for funds (Chou, 2007). Also, within the theoretical postulate of the financial innovation-growth hypothesis, it is posited that financial innovation do results in the emergence of new financial technologies such as modern payment channels such as the Automated Teller Machines (ATMs), the Mobile Banking, Point of Sale (POS) banking transactions, and Internet banking transactions, which reduces transaction costs and promotes the productivity of capital.

On the other side of the argument, the financial innovation-fragility version considers financial innovation from the sceptical view point or dark side. According to this version, financial innovation is the responsible factor causing financial crises because the process of financial innovation does culminate in unprecedented increase in the creation of credit, which makes for the initial boom and thereafter the burst (Brunnermeier, 2009). It is argued that financial innovation provides financial institutions opportunity to design and create structured products capable of exploiting investors' misunderstandings of the financial markets (Henderson and Pearson, 2011). Furthermore, it is argued that financial innovation driven by arbitrage regulation does not allow for efficient allocation of resources but rather reinforces financial fragility which adversely affects effective implementation of monetary policy (Houston et al., 2010).

\subsection{Diffusion of Innovation Theory}

The diffusion of innovation theory was first propounded by Rogers in 1962. This theory is an attempt to explain the process through which new ideas and technology spread across the social system. According to the diffusion of innovation theory, the process of technology adoption does not take place concurrently in a social system but that it is a process whereby some people are disposed to the adoption of an innovation in advance of others.

From the innovation point of view, the diffusion of innovation theory has been applied to explain the adoption of technology. Rogers (1995) argued that the process of technology diffusion comprises four aspects, namely an innovation or new technology itself, the social system, the communication channels of the social system, and time horizon. This process as advanced in the theory is dependent on the level of human capital development. Thus, the higher the level of human capital, the faster the process of innovation transfer and adoption.

Since the formulation of the diffusion of innovation theory, it has been applied in numerous areas, including the financial system. For instance, the revolution in information and communication technology has resulted to financial innovation which led to the proliferation of new financial instruments, products and services, and new forms of organization structure in the financial system. Financial innovation by way of new financial instruments such as Automated Teller Machines (ATMs), internet banking, mobile banking, Point of Sales (POS) evolved as a result of diffusion of innovation in the form of information and communication technology (ICT) into the financial system.

\subsection{The Classical Theory of Money Demand}

The classical theory of money demand is embedded in the quantity theory propounded by Irving Fisher in 1911. Although, the classical economists did not explicitly propound the theory of money demand, but their views are inherent in the quantity theory. In the classical theory, the demand for money is meant for transactions purposes as money is demanded for payment for goods and services. In other words, people demand money solely for transaction purpose and the more money people need for transactional purpose, the more money they will demand (Jhingan, 
2004). This relationship between money demand and the level of transaction is expressed in the equation of exchange expressed as:

$$
\mathrm{MV}=\mathrm{PY}
$$

Where:

$\mathrm{M}=$ the total quantity of money; $\mathrm{V}=$ velocity of money circulation; $\mathrm{P}=$ the general price level and $\mathrm{T}=$ total amount of goods and services exchanged for money.

Equation (1) states that the quantity of money multiplied by the number of times money changes hands in a given year must be equal to nominal income (the total nominal amount spent on goods and services in that year). Fisher assumed velocity of money circulation to be reasonably constant in the short-run. His view of short-run constant velocity transforms the equation of exchange into the quantity theory of money demand.

To show that the quantity theory of money is indeed a theory of money demand can be seen by dividing both sides of the equation (1) by $\mathrm{V}$ to yield:

$$
\mathrm{M}=(1 / \mathrm{V}) \mathrm{PY} \text {. }
$$

Since at equilibrium, the quantity of money $(M)$ that people hold equal to the quantity of money demand $\left(M^{d}\right)$. Hence, $M$ in equation (2) can be replaced by $M^{d}$ using $k$ to represent the quantity, $(1 / \mathrm{V})$, so that equation (2) can be rewritten as:

$$
\mathrm{M}^{\mathrm{d}}=\mathrm{KPY} .
$$

Since $k$ is a constant, the level of transactions generated by a fixed level of nominal income $P Y$ determines the quantity of money $M d$ that people demand. In this regard, Fisher's quantity theory of money suggests a money demand function is determined by income only, with interest rates having no effect.

\subsection{Keynes's Liquidity Preference Theory}

The liquidity preference theory of money demand was propounded by Keynes (1936). In his famous book "The General Theory of Employment, Interest and Money", Keynes identified three motives people demand for money to include: the transactional motive, the precautionary motive and the speculative motive. Keynes believed that the demand for real money balances depends on both interest rate and income. According to Keynes, transactional and precautionary motives are positively related with income. Moreover, Keynes argued that money demand for speculative motive is negatively related to interest rate. From the three motivates of Keynes, a preliminary money demand equation can be expressed as:

$\mathrm{M}_{\mathrm{d}}=\mathrm{M}_{\mathrm{t}}+\mathrm{M}_{\mathrm{p}}+\mathrm{M}_{\mathrm{sp}}$

Where: $M_{d}$ is money demand, $M_{t}$ is transaction demand for money, $M_{p}$ is the precautionary demand for money and $\mathrm{M}_{\mathrm{sp}}$ is the speculative demand for money. Keynes holds that transactions demand for money and precautionary demand for money is the function of income, while money demanded for speculative purposes is a function of interest rate. Hence, the Keynesian money demand function in an explicit form is expressed as:

$\mathrm{Md} / \mathrm{P}=\alpha_{0}+\alpha_{1} \mathrm{Y}-\alpha_{2} \mathrm{i}+\varepsilon$.

Equation (5) states that money demand has positive relationship with income, but negative relationship with interest rate.

\subsection{Friedman Modern Theory of Money}

Milton Friedman in 1956 developed a theory of the demand for money in a famous article, "The quantity Theory of Money: A Restatement". Fiedman's theory is considered to the modern quantity theory of money. The theory states that a change in money supply will change the price level as long as the demand for money is stable. Such a change according to the theory affects the real value of national and economic activity only in the short-run.

The modern theory indicates that the demand for money should be a function of the resources available to individuals (their wealth) and the expected returns on other assets relative to the expected return on money. Friedman in his empirical study on "Monetary Trends in the United States and the United Kingdom (1982)" formulated the following demand for money function for an individual wealth holder with slightly different notations from his original study of 1956 as:

$$
\mathrm{M} / \mathrm{P}=\mathrm{f}(\mathrm{Y}, \mathrm{W}, \mathrm{Rm}, \mathrm{Rb}, \mathrm{Re}, \mathrm{gp}, \mathrm{u})
$$

Where: $\mathrm{M}=$ the total stock of money demanded; $\mathrm{P}=$ the price level; $\mathrm{Y}=$ the real income; $\mathrm{W}=$ the fraction of wealth in non-human form, $\mathrm{R}_{\mathrm{m}}=$ the expected nominal rate of returns on money, $\mathrm{R}_{\mathrm{b}}=$ expected rate of returns on bonds, including expected changes in their prices, $\mathrm{R}_{\mathrm{e}}=$ expected rate of returns on equities, including expected changes in their prices, $g_{p}=(\mathrm{I} / \mathrm{P})(\mathrm{dP} / \mathrm{dt})=$ expected rate of change of prices of goods and hence expected nominal rate of return on physical assets, and $\mathrm{u}=$ variables other than income that may affect the utility attached to the services of money.

In Friedman's restatement the quantity theory of money, the supply of money is independent of the demand for money. The supply of money is unstable due to the actions of monetary authorities. On the other hand, the demand for money is stable.

\section{Methodology}

The model for this study is anchored on the eclectic approach based on the Keynesian theory of money demand and the financial - innovation hypothesis. According to the Keynesian theory, demand for money is a positive function of income and a negative function of interest rate. According to the financial innovation hypothesis, 
financial innovation usually results in the emergence of new financial products and services by way of emergence of sophisticated payment channels such as Automated Teller Machines (ATMs), Point of Sales (POS), Internet banking, and Mobile banking transactions. However, since the main focus of this study is to specifically examine the impact of financial innovation on demand for money function, the traditional determinants of money demand such as income and interest rate are dropped from the model to give way for the examination of the impact of financial innovation on demand for money function.

The dependent variable is the demand for money, while the independent variables include modern financial transaction channels such as the Automated Teller Machines, Mobile banking transactions, Point of Sale (POS) and Internet banking transactions. Thus, the empirical model for this study can be formulated and expressed as:

$$
\mathrm{MD}=\mathrm{f}(\mathrm{ATMVO}, \mathrm{POSV}, \mathrm{NETV}, \mathrm{MOBV})
$$

Where:

$\mathrm{MD}=$ money demand, represented by broad money supply in Nigeria (in million naira)

ATMV = volume of Automated Teller Machines transactions (in millions)

POSV $=$ volume of point of sales transactions (in millions)

NETV = volume of internet banking transactions (in millions)

MOBV = volume of mobile banking transactions (in millions)

The econometric log linear form of equation (7) can be expressed as follows:

$$
\text { LMD }=\omega_{0}+\omega_{1} \text { LATMV }+\omega_{2} \text { LPOSV }+\omega_{3} \text { LNETV }+\omega_{4} \text { LMOBV }+\mathrm{U}
$$

...............................................

Where: $\omega_{0}$ to $\omega_{4}$ are the parameters to be estimated and $U_{3}$ is the random error term.

The theoretical expectations concerning the signs of the parameters are as follows: $\omega_{1}<0, \omega_{2}<0, \omega_{3}<0, \omega_{4}<0$

\subsection{Estimation Technique/Procedures}

The study made use of ordinary least square (OLS) regression technique. The reason for employing the classical Ordinary Least Squares (OLS) is that of all classes of estimators, the Ordinary Least Squares (OLS) is the Best Linear Unbiased Estimator (BLUE) because it has minimum error. However, before the model was estimated, several pre-estimation tests were carried out to ascertain the adequacy of the model. The unit root test was carried out to determine the order of integration of the variables. The unit root test is conducted using the Augmented Dickey-Fuller (ADF) test. The Augmented Dickey-Fuller (ADF) test equation can be expressed as:

$$
\Delta y_{t}=\alpha_{0}+\gamma y_{t-1}+\sum_{i=1}^{k} \beta_{i} \Delta y_{t-i}+U_{t}
$$

Where: $\Delta y_{t}=y_{t}-y_{t-1}$ is the difference of series $y_{t}$; and $\Delta y_{t-1}=y_{t-1}-y_{t-2}$ is the first difference of $\mathrm{Y}_{\mathrm{t}}$ ${ }_{1} ; \alpha_{0}, \gamma$, and $\beta_{\mathrm{i}}$, are parameters to be estimated and $\mathrm{U}_{\mathrm{t}}$, is error term. We accept the null hypothesis of the presence of unit root if $\gamma=0$ and reject it if $\gamma<0$.

The cointegration test is carried out to determine if there exist long run relationship or not among the variables. The Johansen and Juselius (1990) multivariate approach was employed, making use of the trace test and the maximum eigenvalue test. The cointegration equation based on the vector autoregression specification can be expressed as:

$$
\Delta y_{t}=\Pi y_{t-1}+\sum_{i=1}^{k-1} \Gamma_{i} \Delta y_{t-i}+C+\varepsilon_{t}
$$

Where: $\Delta \mathrm{Yt}=\mathrm{n} \times 1$ vector of the variables in period $\mathrm{t} ; \Gamma i=\mathrm{i}=1 \ldots \mathrm{k}-1$ is the $\mathrm{n} \times \mathrm{n}$ matrix of coefficient of the short run specification; $\mathrm{C}=\mathrm{n} \times 1$ vector of the constant term; $\Pi=$ the $\mathrm{n} \times \mathrm{n}$ matrix of the long run impact; and $\varepsilon_{\mathrm{t}}=\mathrm{n}$ $x 1$ vector of error term. The null hypothesis is that $\mathrm{H}_{0}: \beta \mathrm{i}=0$ (there is no long run relationship among the variables) and $\mathrm{H}_{\mathrm{A}}: \beta \mathrm{i} \neq 0$ (there a long run relationship among the variables). To reach an acceptable conclusion for the presence of cointegration, at least one cointegrating equation must be established otherwise there is no cointegration among them. That is, if at least one computed test value is greater than the test critical value at the 5\% level of significance, then we can conclude that there is long run association among the variables.

Lastly, the error correction model is specified aimed at estimating the short run dynamics of the model. The error correction model based on equation (7) can be expressed as:

$\triangle L M D_{t}=$

$\beta_{0}+\sum_{i=1}^{k} \delta_{i} \Delta L M D_{t-i}+\sum_{i=0}^{k} \phi_{i} \Delta L A T M V_{t-i}+\sum_{i=0}^{k} \pi_{i} \Delta L P O S_{t-i}+\sum_{i=0}^{k} \varpi_{i} \Delta L N E T_{t-i}+\sum_{i=0}^{k} \psi_{i} \Delta L M O B V_{t-i}+$

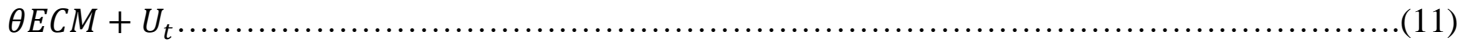

Where: ECM is the error correction factor and $\mathrm{U}$ is the error term.

\subsection{Data Sources and Description}

Secondary source of data is used as the main method of data collection. The relevant data for this study were obtained from the Central Bank of Nigeria (CBN) Annual Report and Statement of Account, Central Bank of Nigeria (CBN) Statistical Bulletin. The study was based on time series data collected on quarterly basis from the period 2009 to 2019. Money demand is measured in millions of naira and was obtained from the Central Bank of Nigeria (CBN) Statistical Bulletin (various years). volume of Automated Teller Machines transactions, volume of mobile banking transactions, volume of internet banking transactions and volume of point of sales transactions are all measured in absolute million, being that they are number of transactions in each of the payment channels. Data on them were also obtained from the Central Bank of Nigeria (CBN) Statistical Bulletin (various years). 


\section{Analysis of Results \\ 4.1. Descriptive Statistics}

Table 1 presents descriptive statistics on the captured variables in this study. Data as presented in the table showed that the mean values of money demand, volume of Automated Teller Machines transactions, volume of mobile banking transactions, volume of internet banking transactions and volume of point of sales transactions were N17,980,699 million, 116,533,258 million, 14,056,366 million, 5,053,968 million and 23,069,857 million, respectively. The maximum values of the variables were $\$ 29,137,800$ million, 239,692,229 million, 159,423,943 million, 28,827,240 million, and 129,574,015 million for money demand, volume of Automated Teller Machines transactions, volume of mobile banking transactions, volume of internet banking transactions and volume of point of sales transactions, respectively. The minimum values of the variables were $\$ 8,997,817$ million, 7,762,869 million, 110,400 million, 289,326 million, 118,620 million, respectively for money demand, volume of Automated Teller Machines transactions, volume of mobile banking transactions, volume of internet banking transactions and volume of point of sales transactions.

Examination of the data in the table showed that the distributions for all the variables were positively skewed, given the positive values of skewness exhibited by the variables. However, examination of Kurtosis showed that the distributions for volume of mobile banking transactions, volume of internet banking transactions and volume of point of sales transactions were leptokurtic, while the distributions for money demand and volume of Automated Teller Machines transactions were platykurtic.

Table-1. Descriptive statistics

\begin{tabular}{l|l|l|l|l|l}
\hline & MD & ATMV & MOBV & NETV & POSV \\
\hline Mean & 17980699 & $1.17 \mathrm{E}+08$ & 14056366 & 5053968. & 23069857 \\
\hline Median & 17966538 & $1.02 \mathrm{E}+08$ & 6587449. & 1361402. & 4870795. \\
\hline Maximum & 29137800 & $2.40 \mathrm{E}+08$ & $1.59 \mathrm{E}+08$ & 28827240 & $1.30 \mathrm{E}+08$ \\
\hline Minimum & 8997817. & 7762869. & 110400.0 & 289326.0 & 118620.0 \\
\hline Std. Dev. & 5860870. & 68414865 & 29502310 & 7761563. & 36002755 \\
\hline Skewness & 0.203271 & 0.236930 & 3.772866 & 1.980668 & 1.673927 \\
\hline Kurtosis & 1.873787 & 1.948256 & 17.25064 & 5.851182 & 4.584059 \\
\hline Jarque-Bera & 2.628326 & 2.439632 & 476.7011 & 43.67261 & 25.14851 \\
\hline Probability & 0.268699 & 0.295285 & 0.000000 & 0.000000 & 0.000003 \\
\hline Sum & $7.91 \mathrm{E}+08$ & $5.13 \mathrm{E}+09$ & $6.18 \mathrm{E}+08$ & $2.22 \mathrm{E}+08$ & $1.02 \mathrm{E}+09$ \\
\hline Sum Sq. Dev. & $1.48 \mathrm{E}+15$ & $2.01 \mathrm{E}+17$ & $3.74 \mathrm{E}+16$ & $2.59 \mathrm{E}+15$ & $5.57 \mathrm{E}+16$ \\
\hline Observations & 44 & 44 & 44 & 44 & 44 \\
\hline Source: Authors' computation, 2020 & & &
\end{tabular}

\subsection{Unit Root Test}

Given the times series nature of the data used, the study carried out the unit root test to ascertain the stationarity properties of the variables. This was carried out to avoid estimating a spurious regression. The test was conducted using the Augmented Dickey-Fuller (ADF) test. The test result is presented in table 2.

Table-2. Unit root test - Augmented Dickey-Fuller (ADF) test

\begin{tabular}{l|l|l|l|l|l}
\hline Variable & ADF Statistic & \multicolumn{2}{l}{ Remarks } \\
\hline & Level & $\mathbf{5 \%}$ Critical Value & 1st Diff. & $\mathbf{5 \%}$ Critical Value & \\
\hline LMD & -1.091688 & -2.936942 & -6.738966 & -2.931404 & $\mathrm{I}(1)$ \\
\hline LATMV & -1.472401 & -2.931404 & -6.441519 & -2.933158 & $\mathrm{I}(1)$ \\
\hline LPOSV & -0.027050 & -2.933158 & -8.680675 & -2.933158 & $\mathrm{I}(1)$ \\
\hline LNETV & -0.196231 & -2.933158 & -7.549894 & -2.933158 & $\mathrm{I}(1)$ \\
\hline LMOBV & -0.867801 & -2.931404 & -8.316712 & -2.933158 & $\mathrm{I}(1)$ \\
\hline
\end{tabular}

The result as depicted in the table using the Augmented Dickey-Fuller (ADF) test showed that no variable was stationary at level since the computed ADF statistic values in absolute terms were less than the critical values at the $5 \%$ level of significance. Based on this result, the null hypothesis of absence of unit root cannot be rejected. However, at the first difference of the variables, they were all found to be stationary. That means all other variables plus inflation rate were stationary after their first difference, and hence were integrated of the first order.

\subsection{Cointegration Test}

The cointegration test was conducted to evaluate whether or not the variables have long run relationship. The Johansen multivariate approach to cointegration was employed in carrying out the test. The cointegration analysis made use of the trace test and the maximum eigenvalue test. The results of the test are presented in tables 3 and 4 . 
Table-3. Trace test

\begin{tabular}{l|l|l|l|l}
\hline Hypothesized & & Trace & $\mathbf{0 . 0 5}$ & \\
\hline No. of CE(s) & Eigenvalue & Statistic & Critical Value & Prob.** \\
\hline None * & 0.589613 & 110.4694 & 69.81889 & 0.0000 \\
\hline At most 1 * & 0.550918 & 73.95259 & 47.85613 & 0.0000 \\
\hline At most 2 $*$ & 0.482809 & 41.13001 & 29.79707 & 0.0017 \\
\hline At most 3 & 0.254096 & 14.09691 & 15.49471 & 0.0803 \\
\hline At most 4 & 0.049406 & 2.077412 & 3.841466 & 0.1495 \\
\hline
\end{tabular}

Source: Authors' computation, 2020

Table-4. Maximum Eigen value test

\begin{tabular}{|c|c|c|c|c|}
\hline Hypothesized & & Max-Eigen & 0.05 & \\
\hline No. of CE(s) & Eigenvalue & Statistic & Critical Value & Prob.** \\
\hline None * & 0.589613 & 36.51681 & 33.87687 & 0.0236 \\
\hline At most $1 *$ & 0.550918 & 32.82258 & 27.58434 & 0.0097 \\
\hline At most $2 *$ & 0.482809 & 27.03310 & 21.13162 & 0.0066 \\
\hline At most 3 & 0.254096 & 12.01949 & 14.26460 & 0.1099 \\
\hline At most 4 & 0.049406 & 2.077412 & 3.841466 & 0.1495 \\
\hline \multicolumn{5}{|c|}{ Max-eigenvalue test indicates 3 cointegrating eqn(s) at the 0.05 level } \\
\hline \multicolumn{5}{|c|}{$*$ denotes rejection of the hypothesis at the 0.05 level } \\
\hline \multicolumn{4}{|c|}{ **MacKinnon-Haug-Michelis (1999) p-values } & \\
\hline
\end{tabular}

The result of the cointegration analysis using both the trace test and the maximum eigenvalue test revealed the establishment of three cointegrating equations, respectively. This is so because both trace and maximum eigenvalue statistics in each of the three cointegrating equations were greater than their respective critical values at the 5\% level of significance. Given these results, the study concluded that there is cointegration and hence existence of long-run relationship among the variables.

\subsection{Granger Causality Test}

The result of the pairwise granger causality test for the causal relationship among the variables is depicted in table 5 .

Table-5. Granger causality test

\begin{tabular}{|c|c|c|c|}
\hline Null Hypothesis: & Obs & $\begin{array}{l}\text { F- } \\
\text { Statistic }\end{array}$ & Prob. \\
\hline ATMV does not Granger Cause MD & 42 & 0.68845 & 0.5087 \\
\hline MD does not Granger Cause ATMV & & 4.14863 & 0.0237 \\
\hline MOBV does not Granger Cause MD & 42 & 1.63489 & 0.2087 \\
\hline MD does not Granger Cause MOBV & & 0.76901 & 0.4707 \\
\hline NETV does not Granger Cause MD & 42 & 0.28030 & 0.7571 \\
\hline MD does not Granger Cause NETV & & 2.47879 & 0.0977 \\
\hline POSV does not Granger Cause MD & 42 & 0.56646 & 0.5724 \\
\hline MD does not Granger Cause POSV & & 2.71315 & 0.0795 \\
\hline
\end{tabular}

Source: Author's computation, 2020

Result of the granger causality analysis showed that there is unidirectional relationship running from money demand to volume of Automated Teller Machines (ATMs) transactions. This means that money demand granger caused volume of Automated Teller Machines. There was also unidirectional relationship running from money demand to volume of internet banking transactions. Furthermore, there was unidirectional relationship running from money demand to volume of point of sales (POS) transactions. This implies that money demand granger caused both internet banking transactions and point of sales transactions. Lastly, there was causality relationship between money demand and mobile banking transactions.

\subsection{Over-Parameterized Result}

The result of the over-parameterized model for the effect of financial innovation on demand for money in Nigeria is depicted in table 6. 
Table-6. Over-parameterized result of the financial Innovation-Economic growth nexus

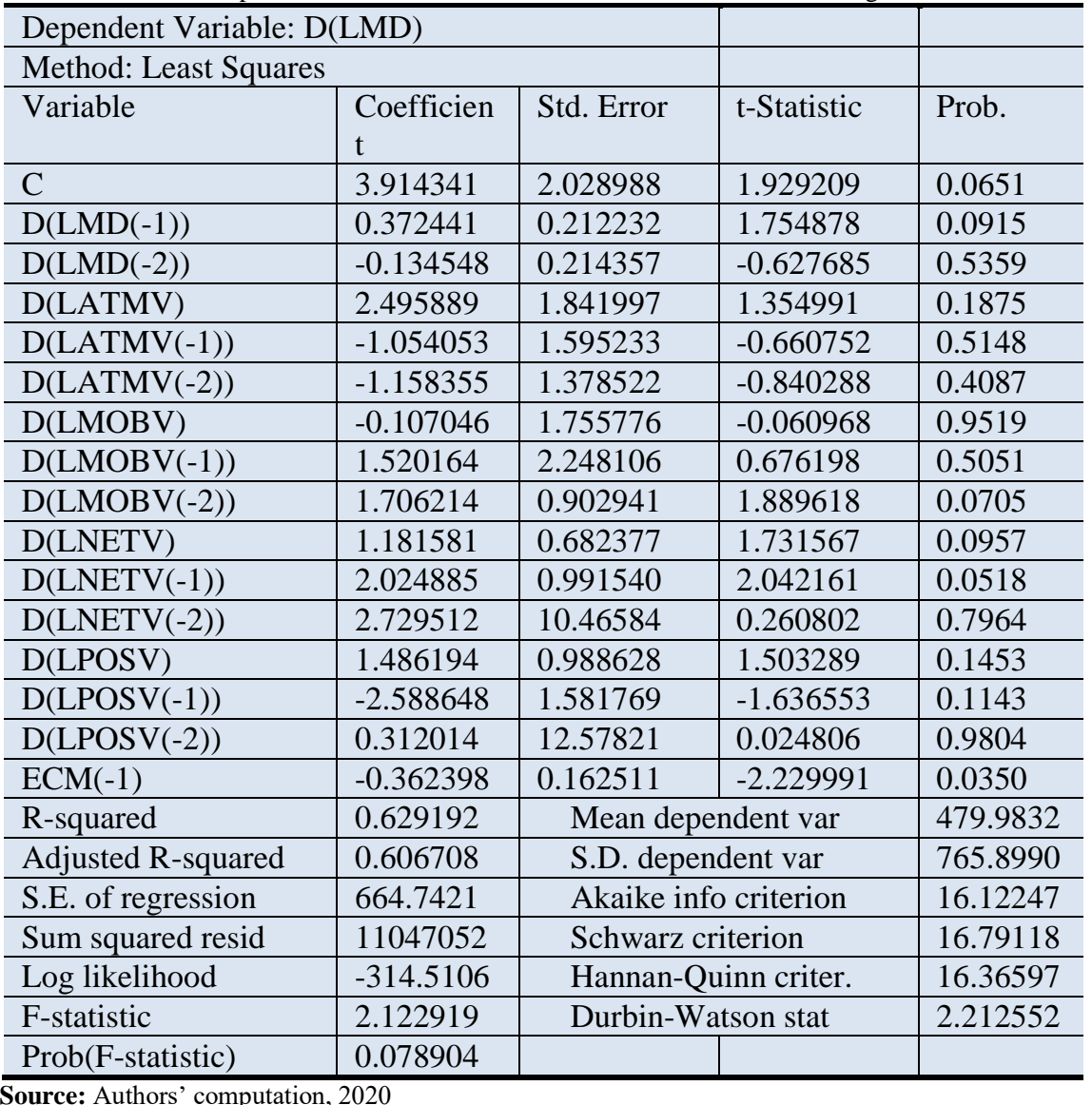

The over-parameterized result as presented in table 6 showed that the error correction factor turned out with the negative co-efficient and was statistically significant in consonance with theoretical expectation. Its co-efficient of 0.362 showed that approximately $36 \%$ of the disequilibrium in the financial innovation-demand for money equation was corrected within a quarter. This is indeed a slow speed of adjustment from the disequilibrium in the short run to the equilibrium in the long run.

The R-squared value of 0.629 and adjusted R-squared value of 0.606 showed that the estimated equation has a good fit on the data. In particular, the adjusted R-squared of 0.606 indicated that about $61 \%$ of the total variation in the dependent variable was explained by variations in the independent variables. The model therefore has a moderately high explanatory power.

In the same vein, the F-statistic of 2.123 with its low probability value of 0.078904 showed that the overall model was statistically significant at the $10 \%$ level of significance. This means that the independent variables have joint impact on the dependent variable. Meanwhile, the Durbin-Watson statistic of 2.21 showed that there was no problem of autocorrelation among the residuals in the model. This means that the model was well specified and wellbehaved.

\subsection{Parsimonious Result}

The parsimonious result was arrived by selecting the statistically significant variables and other variables of interest and used in estimating the parsimonious result. The parsimonious result is presented in table 7. 
Table-7. Parsimonious result

\begin{tabular}{|c|c|c|c|c|}
\hline \multicolumn{5}{|c|}{ Dependent Variable: D(LMD) } \\
\hline \multicolumn{5}{|c|}{ Method: Least Squares } \\
\hline Variable & Coefficient & Std. Error & t-Statistic & Prob. \\
\hline $\mathrm{C}$ & 2.360817 & 1.666585 & 1.416560 & 0.1663 \\
\hline $\mathrm{D}(\mathrm{LMD}(-1))$ & 0.296237 & 0.174801 & 1.694712 & 0.0998 \\
\hline D(LATMV) & 2.026825 & 1.550751 & 1.306996 & 0.2005 \\
\hline $\mathrm{D}(\mathrm{LMOBV}(-2))$ & 1.122177 & 0.570748 & 1.966151 & 0.0580 \\
\hline D(LNETV) & 9.723837 & 5.060283 & 1.921599 & 0.0636 \\
\hline D(LNETV(-1)) & 1.820830 & 0.787468 & 2.312260 & 0.0274 \\
\hline D(LPOSV) & 1.505931 & 0.568976 & 2.646739 & 0.0125 \\
\hline $\mathrm{D}(\mathrm{LPOSV}(-1))$ & -1.902496 & 0.720258 & -2.641409 & 0.0127 \\
\hline $\operatorname{ECM}(-1)$ & -0.315648 & 0.116412 & -2.711463 & 0.0107 \\
\hline R-squared & 0.564393 & \multicolumn{2}{|c|}{ Mean dependent var } & 479.9832 \\
\hline Adjusted R-squared & 0.530492 & \multicolumn{2}{|c|}{ S.D. dependent var } & 765.8990 \\
\hline S.E. of regression & 626.6853 & \multicolumn{2}{|c|}{ Akaike info criterion } & 15.90995 \\
\hline Sum squared resid & 12567502 & \multicolumn{2}{|c|}{ Schwarz criterion } & 16.28610 \\
\hline Log likelihood & -317.1541 & \multicolumn{2}{|c|}{ Hannan-Quinn criter. } & 16.04693 \\
\hline F-statistic & 3.468168 & \multicolumn{2}{|c|}{ Durbin-Watson stat } & 1.935260 \\
\hline Prob(F-statistic) & 0.005481 & & & \\
\hline
\end{tabular}

Source: Authors' computation, 2020

The result as indicated in the table, the error correction variable has the expected negative coefficient and was statistically significant in line with theoretical expectation. The ECM's coefficient of 0.315 showed that about $32 \%$ of the disequilibrium in the system is eliminated within one quarter. This is a slow speed of adjustment from short run disequilibrium to long run equilibrium. The adjusted R-squared of 0.530 showed that the estimated equation has a good fit and moderately high explanatory power. Specifically, about $53 \%$ of the total variation in the dependent variable was accounted for by the independent variables. The F-statistic of 3.468 with its low probability value of 0.005481 showed that the overall model is statistically significant at the conventional $1 \%, 5 \%$ and $10 \%$ levels of significance. This means that the independent variables have joint impact on the dependent variable. Meanwhile, the Durbin-Watson statistic of 1.935 showed that there is no problem of autocorrelation in the model.

Analysis of the short run coefficients showed that one period lagged of money demand has a positive relationship with the current value of money demand in Nigeria in line with a priori expectation. This indicated that a $1 \%$ increase in the previous one period of money demand resulted in an increase in the current value of money demand by approximately $0.30 \%$, ceteris paribus. Statistically, the variable was statistically significant in its effect on the current period's money demand at the $10 \%$ level of significance, given its low probability value of 0.0998 .

The volume of Automated Teller Machine (ATM) transactions has a positive effect on money demand in Nigeria. This shows that a $1 \%$ increase in the volume of ATM transactions resulted in an increase in money demand by approximately $2.03 \%$, ceteris paribus. The variable was however not statistically significant in influencing money demand at any of the conventional 1\%,5\% and 10\% levels of significance, given its high probability value of 0.2005 .

The result showed that the volume of mobile banking transactions has a positive relationship with money demand in Nigeria. This result in real term shows that a $1 \%$ increase in two periods lagged volume of mobile banking transactions led to an increase in money demand by approximately $1.12 \%$, other factors held constant. The variable was also statistically significant in influencing money demand at the $10 \%$ level of significance, given its low probability value of 0.0580 .

Furthermore, volume of internet transactions has a positive relationship with money demand in Nigeria. In real term, the result showed that a $1 \%$ increase in the current and one period lagged volume of internet transaction led to an increase in money demand by about $9.72 \%$ and $1.82 \%$, respectively. The variables were also statistically significant in influencing money demand in Nigeria. While current period's volume of internet transactions was significant at the $10 \%$ level of significance, given its low probability value of 0.0636 , one period lagged volume of internet transactions was statistically significant at the $5 \%$ level of significance, given its low probability value of 0.0274 .

Lastly, volume of point of sales (POS) transactions in the current period has a positive relationship with money demand in Nigeria. This result in real term showed that a $1 \%$ increase in the current period's volume of point of sales (POS) transactions resulted in an increase in money demand by approximately $1.51 \%$. On the other hand, one period lagged of volume of POS transactions has negative impact on money demand in Nigeria. This, in real term means that a $1 \%$ increase in one period lagged of volume of POS transactions resulted in a decrease in money demand by about $1.90 \%$. The variables were also statistically significant in influencing money demand at the $5 \%$ level of significance, given their low probability values of 0.0125 and 0.0127 , respectively.

\subsection{Stability Test}

The study carried out analysis to test for the stability of money demand function during the period of analysis. The aim was to ascertain whether or not the demand for money function was stable. The test was done using plot of 
cumulative sum of recursive residuals (CUSUM) and plot of cumulative sum of squares of recursive residuals (CUSUMSQ). The results of the stability test are presented in figures 1 and 2 . The plot of CUSUM and CUSUMSQ statistics at $5 \%$ critical lines showed that they clearly wander in between the critical lines, indicating the stability of the demand for money function in Nigeria.

Fig-1. Cumulative sum of recursive residuals (CUSUM) test

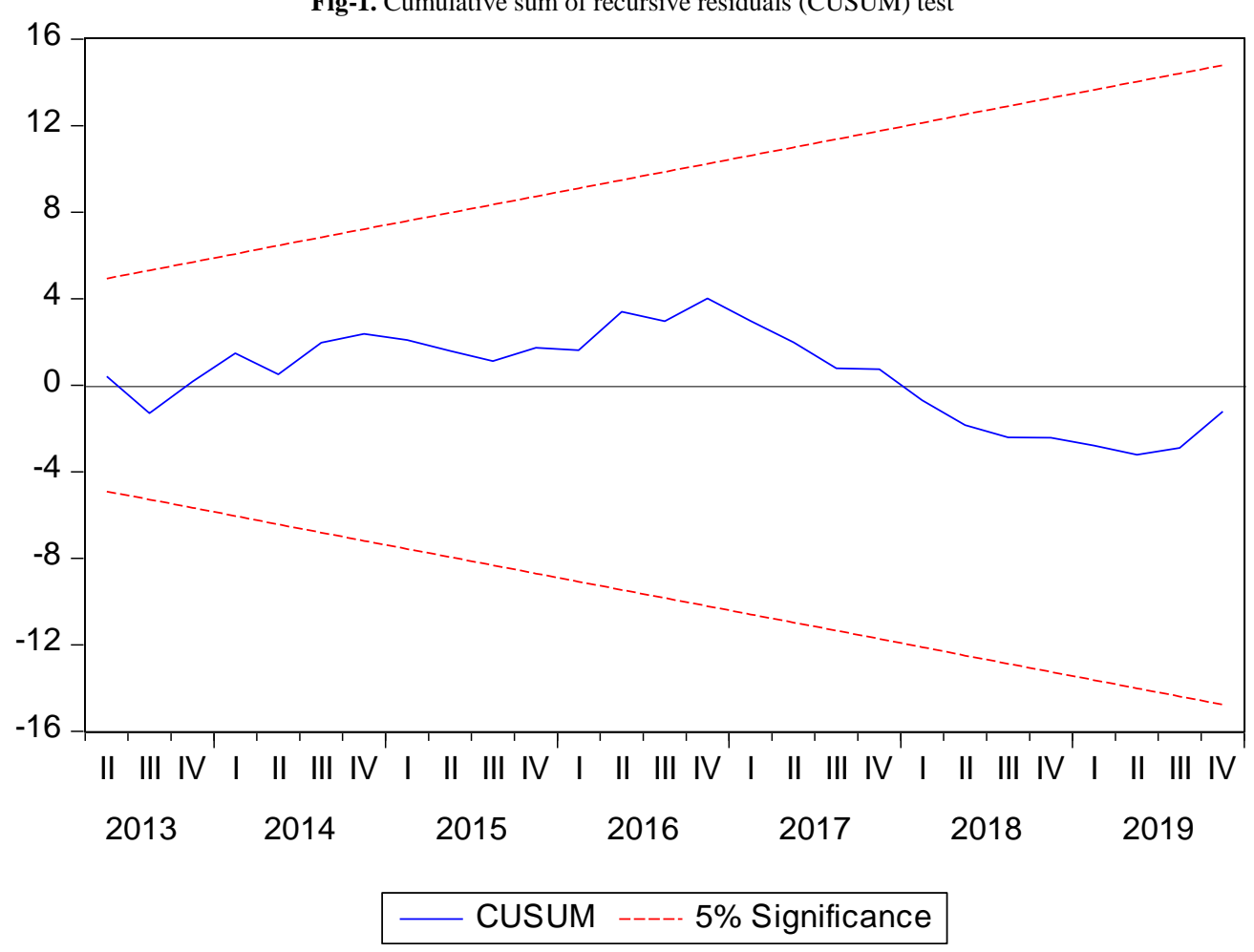

Fig-2. Cumulative sum of squares recursive residuals (CUSUM) test

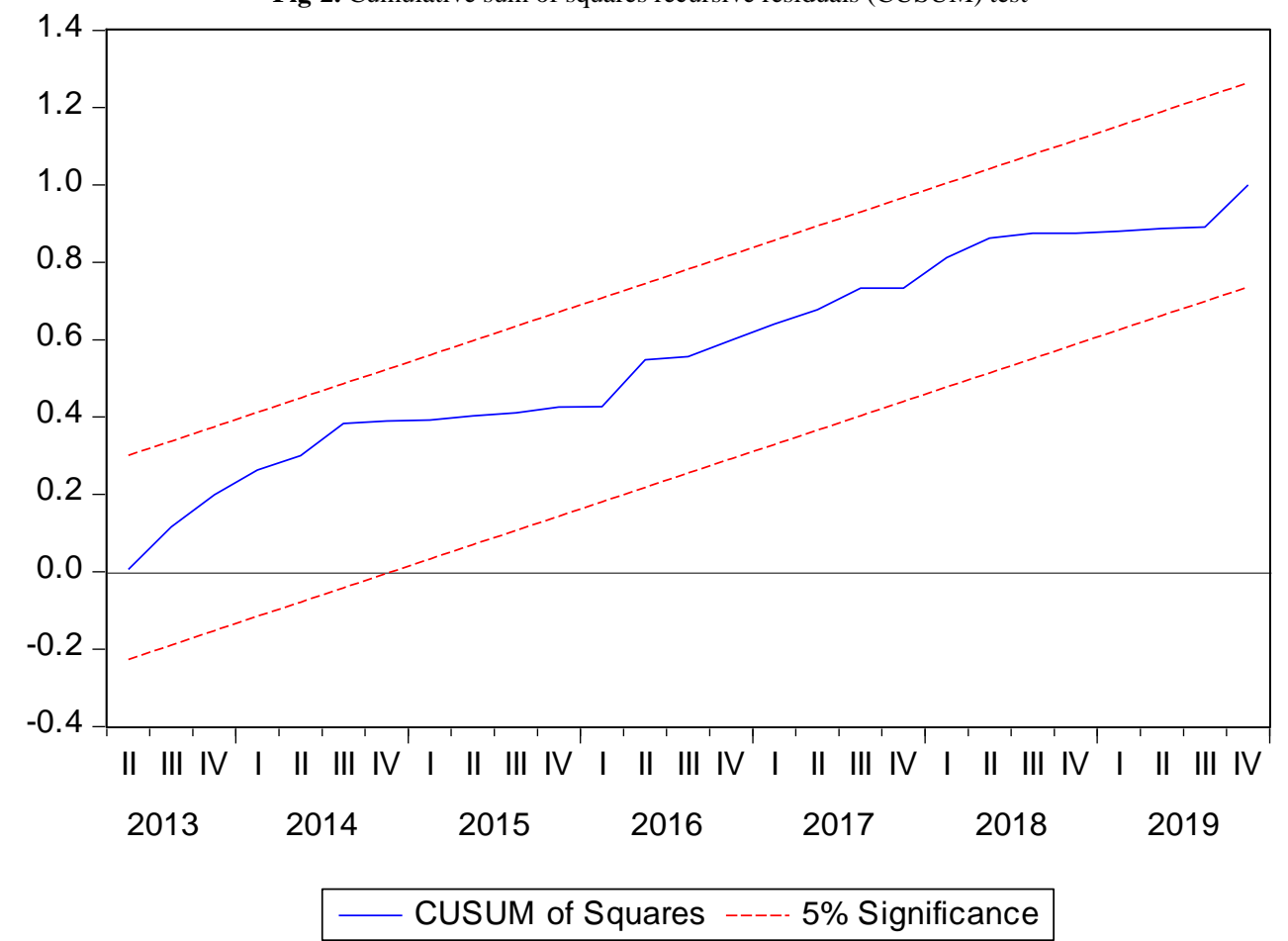

\subsection{Diagnostic Test}

To ascertain the adequacy of the estimated equation, several diagnostic tests were conducted. The results of the tests are summarized in table 8. The Ramsey RESET test statistic of 1.117223 with its high probability value of 0.7348 showed that the estimated demand for money equation is stable in line with the CUSUM and the CUSUMSQ test earlier performed. The Jarque-Bera test for the normality of the estimated equation is depicted in figure 3 and table 8 . The Jarque-Bera test value of 1.117214 with its probability value of 0.572005 confirmed the normality of the estimated equation. Meanwhile, the Breusch-Godfrey serial LM test statistic of 0.098277 with its high probability value of 0.9067 showed that there is no problem of autocorrelation in the model. This indicates that the residuals terms are independent and hence there is no autocorrelation in the estimated equation. Lastly, the Breusch-Pagan- 
Godfrey Heteroscedasticity test value of 0.692790 with its high probability of 0.7441 showed that there is no problem of heteroscedasticity and hence the disturbance terms are normally distributed. The conclusion from the various test conducted showed that the estimated equation is adequate and well-behaved.

Table-8. Diagnostic test

\begin{tabular}{l|l}
\hline Test statistic & Value(prob.) \\
\hline Ramsey RESET Test & 0.117223 \\
& $(0.7348)$ \\
\hline Jarque-Bera test & 1.117214 \\
& $(0.572005)$ \\
\hline Breusch-Godfrey Serial Correlation LM Test & 0.098277 \\
& $(0.9067)$ \\
\hline Breusch-Pagan-Godfrey Heteroscedasticity Test & 0.692790 \\
& $(0.7441)$ \\
\hline
\end{tabular}

Note: values in parenthesis are probability values Source: Author's computation, 2019

Fig-3. Histogram normality test

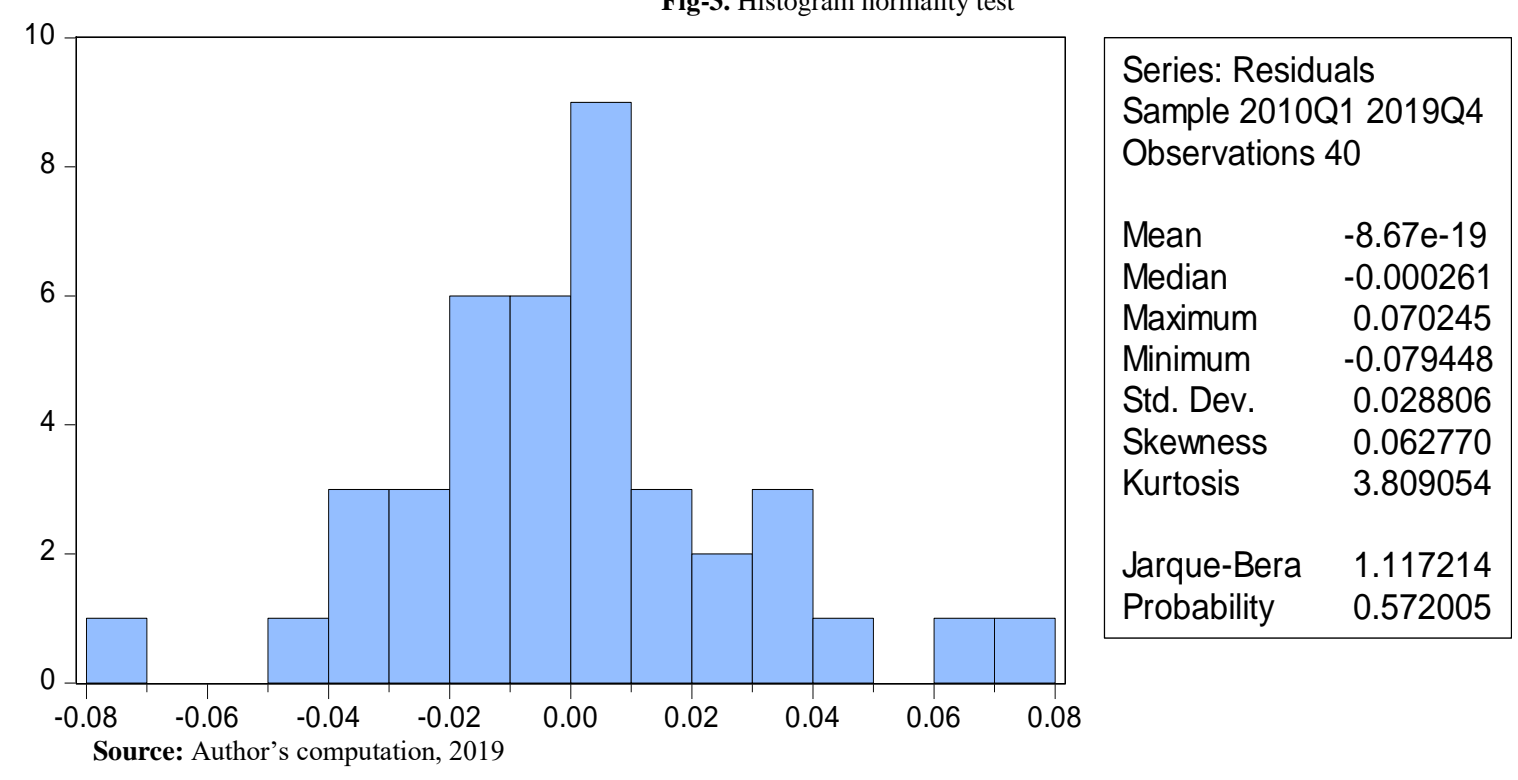

\section{Conclusion and Recommendation}

This study was carried out to investigate the impact of financial innovation on demand for money in Nigeria using quarterly data for the period 2009 - 2019. Theoretical literature has established that financial innovation by way of new financial products and services exert significant influence on the workings of the monetary policy and hence money demand function. Based on this assertion, this study was carried out to investigate this claim for Nigeria employing modern payment channels such as Automated Teller Machines (ATMs) transactions, Point of Sales (POS) transactions, Internet banking transactions, and Mobile banking transactions.

The result obtained showed that financial innovation has mixed impact on money demand in Nigeria during the period of analysis. For instance, financial innovation has positive impact on money demand through volume of ATM transactions in the current period, two periods lagged of volume of mobile banking transactions, current period and one period lagged of volume of internet banking transactions, and current period's volume of Point of Sales (POS) transactions in Nigeria. On the other hand, financial innovation has negative impact on money demand through one period lagged of volume of point of sales in Nigeria. On the stability of the demand for money function, the result of the stability tests based on the CUSUM test and CUSUM of squares test showed that the demand for money function was stable during the evaluation period.

Based on the result, the study recommended that monetary policy strategy of the central bank of Nigeria (CBN) should be fine-tuned to ensure it is well suited to deal with the challenges posed by financial innovation by way of proliferation of sophisticated payment channels. The central bank needs to be anticipatory through proper monitoring of the financial landscape, by following developments closely and by trying to predict the consequences of financial innovations and act quickly to counter any negative effect of financial innovation on the effectiveness of monetary policy. Similarly, a policy of attracting more participants (non-government) and private sector funds to the money market is necessary as this will deepen the market and make the market more dynamic and amenable to monetary policy and counter any adverse effect of financial innovation. 


\section{References}

Aliha, P. M., Sarmidi, T., Shaari, A. H. and Said, F. F. (2017). Investigating the effect of financial innovations on demand for money on a world scale: A systems GMM panel data approach. Journal of Global Business and Social Entrepreneurship (GBSE), 3(5): 181-88.

Allen, F. and Gale, D. (1994). Financial innovation and risk sharing. MIT Press: Cambridge, MA.

Apere, T. O., 2017. "The implications of financial innovations on money demand in Nigeria." In Proceedings of ISER 94th International Conference, Zurich, Switzerland, 16th-17th December 2017.

Berger, A. (2003). The relationship between capital and earnings in banking. Journal of Money, Credit and Banking, 27(2): 432-56.

Brunnermeier, M. K. (2009). Deciphering the liquidity and credit crunch 2007-2008. Journal of Economic Perspectives, 23(1): 77-100.

Chou, Y. K. (2007). Modelling financial innovation and economic growth. Why the financial sector matters to the real economy? The Journal of Economic Education, 38(1): 78-91.

Gbadebo, O. O. (2010). Does financial innovation affect the demand for money in Nigeria? Asian Journal of Business Management Studies, 1(1): 08-18.

Gbadebo, O. O. and Okunrinboye, O. A. (2009). Modelling the Impact of financial innovation on the demand for money in Nigeria. African Journal of Bussiness Management, 3(2): 39-51.

Goldfeld, S. M. (1994). Demand for money: empirical studies, in P. Newman, M. Milgrate and J. Eatwell (Eds) the new palgrave dictionary of money and finance. Macmillan Press: London.

Grinblatt, M. and Longstaff, F. A. (2000). Financial innovation and the role of derivative Securities: An empirical analysis of the treasury STRIPS program. Journal of Finance, 55(3): 1415-36.

Henderson, B. J. and Pearson, N. D. (2011). The dark side of financial innovation: A case study of the pricing of a retail financial product. Journal of Financial Economics, 100(2): 227-47.

Houston, J., Chen, L., Lin, P. and Yue, M. (2010). Creditor rights, information sharing, and bank risk taking. Journal of Financial Economics, 96(3): 485-512.

Hye, Q. M. A. (2009). Financial innovation and demand for money in Pakistan. Asian Economic Review, 51(2): 21928.

Jhingan, M. L. (2004). Macroeconomic theory. 3rd edn: Konark Publishers: Delhi.

Johansen, S. and Juselius, K. (1990). Maximum likelihood estimation and inference on cointegration with application to the demand for money. Oxford Bulletin of Economics and Statistics, 52(2): 169-210.

Keynes, J. M. (1936). The general theory of employment, interest and money. Macmillan Cambridge University Press: New York.

Matthew, A. O., Fasina, F. F., Olowe, O. and Adegboye, F. B. (2010). Empirical modeling of the impact of financial innovation on the demand for money in Nigeria. International Research Journal of Finance and Economics, 58: 73-90. Available: https://www.researchgate.net/publication/257573174_Empirical_Modeling_of the_Impact_of_Financial_In novation

Merton, R. C. (1992). Financial innovation and economic performance. Journal of Applied Corporate Finance, 4(4): 12-22.

Misati, R. N., Lucas, N., Anne, K. and Shem, O. (2010). Financial innovation and monetary policy transmission in Kenya. International Research Journal of Finance and Economics, 50: 123-36. Available: https://www.researchgate.net/publication/288214426

Mujuri, B., Kibet, L. and Kiprop, S. (2018). Effect of financial innovation on money demand in Kenya. Journal of Economics and Sustainable Development, 9(16): 163-82.

Nkoro, E. and Uko, A. (2013). Financial sector development-economic growth nexus: Empirical evidence from Nigeria. American International Journal of Contemporary Research, 3(2): 87-94.

Noyer, C., 2008. "Challenges of financial innovation for the conduct of monetary policy." In Speech delivered at the International Monetary Fund-Bank of France-Bank of England Conference, Paris.

Rogers, E. M. (1995). Diffusion of innovations. 4th edn: The Free Press: New York.

Safdar, S. and Khan, A. (2014). Demand for money, financial innovation and money market disequilibrium. IOSR Journal of Humanities and Social Science, 19(2): 36-41.

Sichei1, M. M. and Kamau, A. W. (2012). Demand for money: Implications for the conduct of monetary policy in Kenya. International Journal of Economics and Finance, 4(8): 72-82.

Solans, E. D., 2003. "Financial innovation and monetary policy." In Excerpts of speech delivered at the 38th SEACEN Governors Conference and 22nd Meeting of the SEACEN Board of Governors on "Structural Change and Growth Prospects in Asia -Challenges to Central Banking", Manila (13 February). 